\title{
Investigation of the Pre-service Science Teachers' Perceptions of Protists
}

\author{
Asli Saylan Kirmizigul ${ }^{1 *}$, Esra Kizilay ${ }^{1}$
}

${ }^{1}$ Erciyes University, TURKEY

*Corresponding Author: aslisaylan@erciyes.edu.tr

Citation: Saylan Kirmizigul, A., \& Kizilay, E. (2020). Investigation of the Pre-service Science Teachers' Perceptions of Protists. Pedagogical Research, 5(4), em0081. https://doi.org/10.29333/pr/9132

\section{ARTICLE INFO}

Received: 22 Apr. 2020

Accepted: 18 Aug. 2020

\begin{abstract}
This study aims to investigate the pre-service science teachers' perceptions of protists. Within this scope, case study design was conducted. The data was collected from purposively chosen 60 third-grade pre-service science teachers from a university in Kayseri, Turkey during the spring semester of 2018-2019. The drawing-writing technique was used for data collection in the study. In the drawing test pre-service teachers were asked to choose three examples for the protists and draw them on the paper given. Moreover, they were asked to write the common features of the protists. The participants' drawings and writings that reveal their conceptual structures regarding the protists were analyzed through content analysis method. The participants' drawings and writings were analyzed based on the rubrics and grouped based on their levels. The percentages of the agreement between two experts regarding the assessment of drawings and writings were measured as 0.92 and 0.90 , respectively, indicating a high reliability. In addition, Chi-square test was applied to the data in order to see whether there is a significant relationship between drawing and writing levels of the pre-service teachers. According to the findings, $11.7 \%$ of the participants had no/ irrelevant drawings and writings, $83.4 \%$ of them had partially correct drawings, and $5 \%$ of them had comprehensive drawings regarding protists. While only one participant wrote all six features for protists, $86.6 \%$ of them had partially correct writings including one to five features for protists. The findings revealed that pre-service teachers' perceptions about the protists were identified as moderate, and there is a significant relationship between the pre-service teachers' drawing and writing levels of protists. According to the (7x7) crosstabulation table, students with a high level of writing also have a high level of drawing and vice versa.
\end{abstract}

Keywords: Protista, conceptual understanding, perception, pre-service science teachers

\section{INTRODUCTION}

Conceptual learning is an important part of science education (Joung \& Gunstone, 2010). Biology, one of the branches of science, has a comprehensive content including abstract concepts. One of these concepts is the microscopic creatures including the protists. Students find difficult to learn the sub concepts of protists such as characteristics and classification of protists, and to give examples of protists (Raharjo, Ramli, \& Rinanto, 2018; Yunanda, Susilo \& Ghofur, 2019). Since the competence of the teacher in the content knowledge is an important factor affecting the students' success towards the course (Bektasli, 2008), pre-service science teachers should have sufficient content knowledge of all concepts of science including the protists before taking school experience and practice teaching courses in their fourth-year at university.

\section{The Concept and Conceptual Understanding}

Individuals develop intellectual skills, cognitive strategies, verbal information, motor skills and attitudes as learning products (Gagné, 1985). Intellectual skills enable individuals to interact with their environment through symbols or conceptualizations (Gagné, Briggs, \& Wager, 1992). Thus, concepts emerge as intellectual tools that enable individuals to understand the world, think and communicate meaningfully (Gagné, Briggs, \& Wager, 1992; Senemoglu, 2009). Concepts are generally divided into concrete and abstract concepts. Learning a concrete concept means that an individual can define object properties, since concrete learning is a prerequisite for learning abstract ideas (Gagné et al., 1992). The ability to recognize concrete concepts is very important for individuals to learn more complex concepts. Therefore, concrete and abstract concepts are at the core of learning (Huebner, 2008). From this point of view, it is very important to determine the conceptual understanding of individuals in order to examine their learning. 


\section{Conceptual Understanding in Science Education}

In recent years, the effect of constructivist learning approach on educational environments has brought up the use of different methods and strategies in determining conceptual understanding and conceptual change (Vance, Miller, \& Hand, 1995). There are many ways to determine conceptual learning. The techniques to elicit students' ideas include drawing, writing, concept mapping, individual or group discussions and concept cartoons (Pope, 2019).

Drawings, in general, are defined as visual representations which are created in two dimensions, showing all kinds of content and produced by the learner (Quillin \& Thomas, 2015). Drawings are used in teaching processes to reveal students' mental models and misconceptions, to associate concepts, to get information about how much individuals learn and what they know (Chang, 2017; Quillin \& Thomas, 2015). The drawings can also be used as an effective assessment tool (Skamp, 2012). Therefore, drawings are used to examine conceptual understandings and opinions of individuals in many studies in science education (Jalmo \& Suwandi, 2018; Nugraha, 2018; Patrick \& Tunnicliffe, 2010; Tunnicliffe, 2011; Yang \& Zhou, 2017). Writing technique is also commonly used in conceptual understanding of individuals (Chen, Hand, \& McDowell, 2013; Eser, Cetin, Ozarslan, \& Isik, 2015).

\section{Concept of Protists and Conceptual Understanding of Protists}

Recent studies redefined previously established taxonomic relationships and suggested a five-kingdom classification of living organisms: 1) Protists, 2) Monerans, 3) Fungi, 4) Plants, 5) Animals (Cain, 2020). On the other hand, many biologists recognize six kingdoms, dividing Monera into Eubacteria and Archeobacteria. However, 5th grade science textbook classified living organisms into four groups: 1) Microscopic creatures (including protists and monerans), 2) Fungi, 3) Plants, 4) Animals (MoNE, 2018). In the textbook, amoeba, euglena, paramecium and different types of bacteria were given as examples of microscopic creatures.

The protists are eukaryotes. Most of them are single-celled and capable of motility. They mostly live in damp or wet locations, and reproduce asexually. Some protists engage in photosynthesis, others ingest or absorb their food, and some others exhibit both autotrophic and heterotrophic nutrition.

There is a limited number of studies that investigate the pre-service teachers' knowledge of microscopic creatures (i.e. Bektasli, 2018; Kurt \& Ekici, 2013; Tekkaya, Capa, \& Yilmaz, 2000). In their study, Tekkaya, Capa and Yilmaz (2000) examined the misconceptions of pre-service biology teachers about biology concepts. When the misconceptions of pre-service teachers about the classification of living things were examined, it was found that approximately half of the participants included paramecium and amoeba in the animal kingdom. Kurt and Ekici (2013) investigated the pre-service biology teachers' cognitive structure on the concept of bacteria. The results of their study revealed that pre-service biology teachers mistake protists for bacteria and viruses. In parallel with this finding, Kalayci (2017), who investigated third and fourth-year pre-service science teachers' conceptual knowledge about eukaryotes and prokaryotes using word association test and drawing-writing technique, stated that some preservice science teachers confused protists with the prokaryotes. Bektasli (2018) investigated pre-service science and biology teachers' knowledge level and misconceptions about archaebacteria, bacteria and protista kingdoms. The results revealed that both pre-service science and biology teachers did not have sufficient knowledge about the three kingdom. Moreover, some preservice teachers have misconceptions that the kingdom protista consists of only single-celled organisms. In addition, pre-service teachers had a perception that the cells of living things in the kingdom protista are prokaryotes. Denis Celiker (2015) conducted a similar research on animal and plant cells with the participation of pre-service science teachers and suggested that this study should be repeated with the drawing-writing technique by including the structures of protists in further studies.

\section{Purpose of the Study}

Above-mentioned studies (Bektasli, 2018; Kalayci, 2017; Tekkaya, Capa, \& Yilmaz, 2000) revealed that pre-service science teachers do not have sufficient knowledge about protists. However, the concept of microscopic creatures including protists is taught to students for the first time in fifth grade in Turkey (MoNE, 2018), and since they are the key persons, it is important preservice science teachers to be knowledgeable about this concept and to express biological creatures by drawing in addition to writing. Since the success of a teacher in his/her profession is directly related to the content knowledge, studies that aim to evaluate pre-service teachers' content knowledge are important in terms of revealing the deficiencies and eliminating the deficiencies.

There is a need for a qualitative study focusing entirely on protists and examining the conceptual understanding, visual perceptions or misconceptions of pre-service science teachers about protists. From this point of view, the aim of the study is to investigate the pre-service science teachers' knowledge of protists. Specifically, this research answered the following research questions: What is the level of knowledge of third-year preservice science teachers about protists? Research answered also the two sub-questions: 1) What is the level in writing skills of preservice science teachers' about the protists? 2) What is the level in drawing skills of preservice science teachers' about the protists?

\section{METHOD}

\section{Research Design}

In this research, descriptive case study was conducted to understand and describe the pre-service science teachers' knowledge of protists in detail (Creswell, 2013). Descriptive case study aims to provide multiple sources of evidence for triangulating the data in an all-encompassing manner (Creswell, 2013). Moreover, using different data collection methods in the same research increases the consistency, intelligibility and actuality of the collected data, and the accuracy of the interpretations (Fraenkel, Wallen, \& Hyun, 2012). Therefore, in this research, not only writings, but also drawings which reveal their conceptual 
structures regarding the protists were analyzed in detail in order to determine the knowledge levels of third-year preservice teachers. Using these different measurement tools in this research it was aimed to collect rich data through data triangulation (Fraenkel et al., 2012). In order to provide an in-depth perspective, the preservice science teachers' drawings and written expressions were given including direct quotations in the findings section.

\section{Participants}

Criterion-based form of purposive sampling was used to determine the participants (Fraenkel et al., 2012). The pre-service science teachers take the courses named as General Biology-I and General Biology-II containing protists concepts in their second year. Additionally, pre-service science teachers take Laboratory Applications in Science Teaching I course during the fall semester of the third year. They have the opportunity to observe some parts of the protists under a microscope in this course. Therefore, third-year pre-service teachers who completed these courses were expected to be knowledgeable about protists. For that reason, all 60 third-year pre-service teachers (51 females and 9 males) enrolled at the education faculty of Erciyes University in Turkey were selected as the sample. The study was conducted in February, 2019.

\section{Data Collection}

The drawing-writing technique was used for data collection. This technique is very effective in obtaining natural and highquality data. It helps to examine the participants' hidden opinions on a specific concept in detail (Reiss \& Tunnicliffe, 2001). Students' drawings, like open-ended writings, are a type of free-response assessment where students construct an answer rather than selecting a provided answer (Slominski, Momsen, \& Montplaisir, 2017). This is the main reason why this technique was used in this study.

In the drawing test, in order to determine their level of knowledge regarding protists, the pre-service science teachers were asked the following question: "Please draw three examples for the protists." In the writing test, they were asked the following question: "Please write the common features of the protists." In the form, the pre-service science teachers were asked to draw and write comprehensively. It was also announced that their answers will be anonymous and the data will be used for an academic publication. In this context, the participants were encoded as P1, P2, ..P60. In order to enable the pre-service teachers to express their knowledge on the subject freely, it was stated that beauty of their drawings will not matter. The data were collected from all participants at one point in time in the biology laboratory. Each pre-service teacher drew the protists and wrote their common features individually using a pencil on a blank A4 sheet of white paper. The participants were given 10-15 minutes for the application of draw-write form.

\section{Data Analysis}

The drawing-writing data regarding the subject of protists were analyzed through content analysis method. Within this framework, the pre-service teachers' answer sheets were assigned numbers as P1, P2...P60. In the analyzes of the drawings, the rubrics for each protist and scoring system (Table 3 ) developed by the researchers were used. The pre-service teachers' writings were analyzed using the answer keys adapted from Britannica (2017). Then, both drawings and writings were grouped based on their levels. Lastly, chi-square test was applied to test whether there is a significant relationship between drawing and writing levels of the pre-service science teachers (King, Rosopa, \& Minium, 2011).

\section{Drawing}

The pre-service science teachers are expected to draw the protists and indicate their basic parts in their drawings. In the analyze of the drawings, the separate rubrics for each protist developed by the researchers were used. While rubrics were being developed, firstly the related studies in literature were examined and the dimensions of each rubric were decided (Britannica, 2017; Ormanci \& Balim, 2016; Reiss \& Tunniclife, 2001). The correct drawings indicating basic parts of the four protists (amoeba, euglena, paramecium and algae) are given in Table 1 as examples. 
Table 1. The correct drawings indicating basic parts of each protist

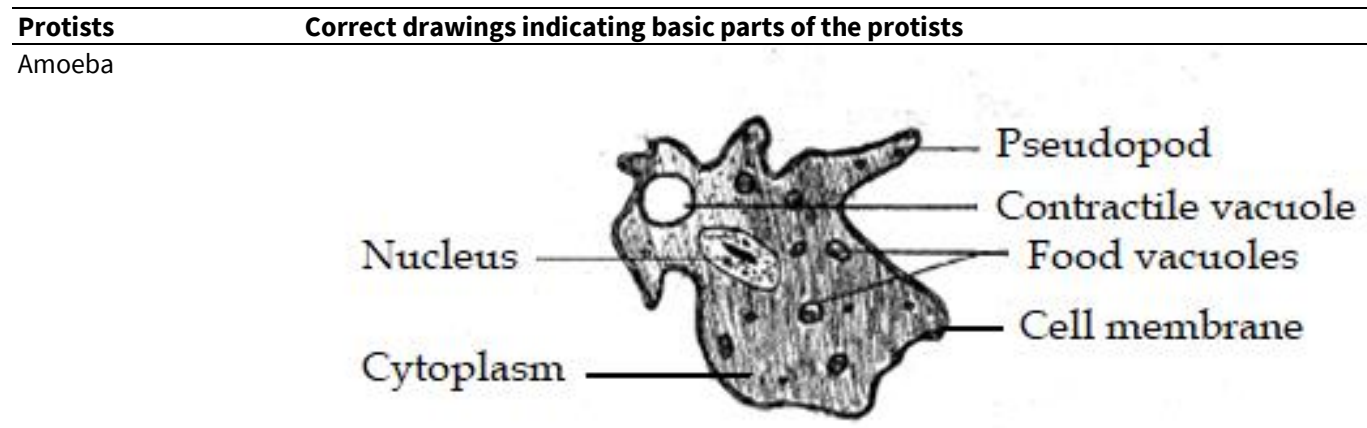

(NCSU, 2004)

Euglena

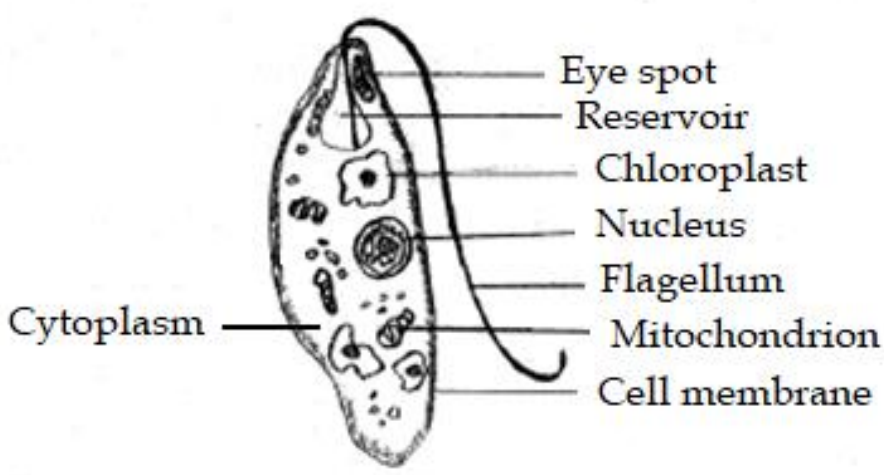

(NCSU, 2004)

Paramecium

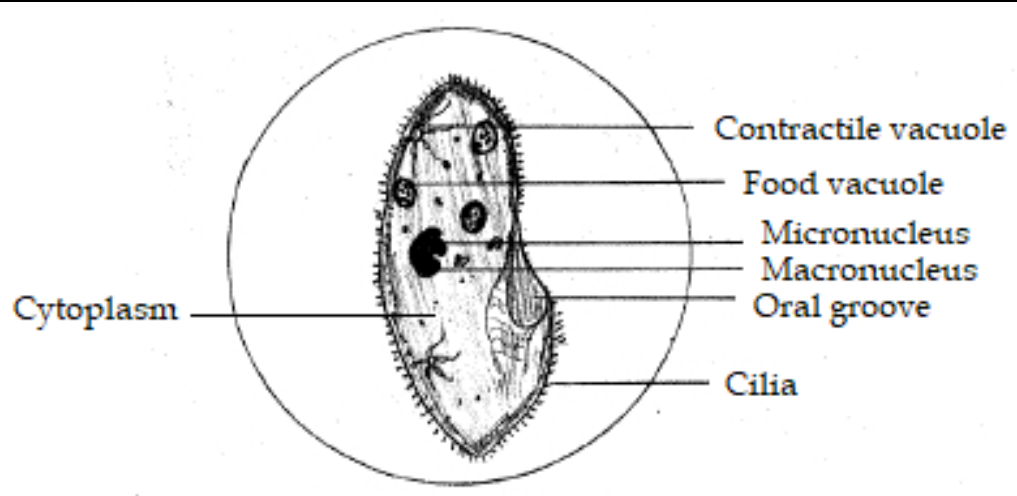

(NCSU, 2004)

Algae

(i.e. Volvox)

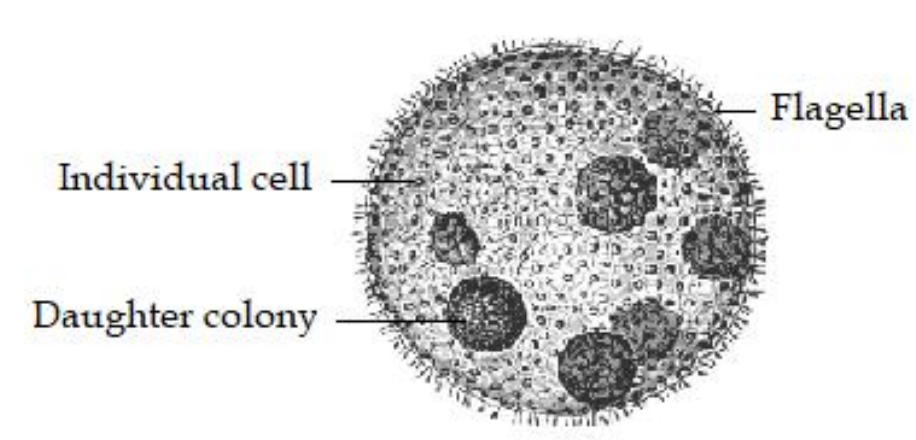

(ETC-USF, 2011)

One of the rubrics is given in Table 2 as an example. The points that participants took from each sub dimension were defined with three different levels as: 'insufficient ( 0 point), limited ( 2 points), and perfect performance ( 4 points)". Since a paramecium has seven basic parts (contractile vacuole, food vacuole, oral groove, cilia, cytoplasm, micro and macronucleus), the highest point to be taken from the rubric regarding paramecium is 28 , and the lowest point is 0 . These points change based on the protist's main parts. For instance, according to the scoring system, the pre-service teacher who draws amoeba completely correct including its six parts (see Table 1 ) will receive 24 points. 
Table 2. Drawing test rubric regarding paramecium

\begin{tabular}{|c|c|c|c|c|c|c|}
\hline \multirow[t]{2}{*}{ Dimension } & \multirow{2}{*}{$\begin{array}{c}\text { Sub-dimension } \\
\text { Contractile } \\
\text { vacuole }\end{array}$} & \multicolumn{2}{|c|}{ Insufficient Performance (0p) } & \multicolumn{2}{|c|}{ Limited Performance (2p) } & \multirow{2}{*}{$\begin{array}{c}\text { Perfect Performance } \\
\text { (4p) } \\
\text { - the shape is correct } \\
\text { - drawn in the right place }\end{array}$} \\
\hline & & $\begin{array}{c}\text { No } \\
\text { drawing }\end{array}$ & $\begin{array}{l}\text { - the shape is incorrect } \\
\text { - drawn in the wrong place }\end{array}$ & $\begin{array}{c}\text { - the shape is correct } \\
\text { - drawn in the wrong place }\end{array}$ & $\begin{array}{l}\text { - the shape is incorrect } \\
\text { - drawn in the right place }\end{array}$ & \\
\hline \multirow{4}{*}{$\begin{array}{l}\text { The Basic } \\
\text { Parts }(20)\end{array}$} & food vacuole & $\begin{array}{c}\text { No } \\
\text { drawing }\end{array}$ & $\begin{array}{l}\text { - the shape is incorrect } \\
\text { - drawn in the wrong place }\end{array}$ & $\begin{array}{c}\text { - the shape is correct } \\
\text { - drawn in the wrong place }\end{array}$ & $\begin{array}{l}\text { - the shape is incorrect } \\
\text { - drawn in the right place }\end{array}$ & $\begin{array}{l}\text { - the shape is correct } \\
\text { - drawn in the right place }\end{array}$ \\
\hline & oral groove & $\begin{array}{c}\text { No } \\
\text { drawing }\end{array}$ & $\begin{array}{l}\text { - the shape is incorrect } \\
\text { - drawn in the wrong place }\end{array}$ & $\begin{array}{c}\text { - the shape is correct } \\
\text { - drawn in the wrong place }\end{array}$ & $\begin{array}{l}\text { - the shape is incorrect } \\
\text { - drawn in the right place }\end{array}$ & $\begin{array}{c}\text { - the shape is correct } \\
\text { - drawn in the right place }\end{array}$ \\
\hline & cilia & $\begin{array}{c}\text { No } \\
\text { drawing }\end{array}$ & $\begin{array}{l}\text { - the shape is incorrect } \\
\text { - drawn in the wrong place }\end{array}$ & $\begin{array}{c}\text { - the shape is correct } \\
\text { - drawn in the wrong place }\end{array}$ & $\begin{array}{l}\text { - the shape is incorrect } \\
\text { - drawn in the right place }\end{array}$ & $\begin{array}{l}\text { - the shape is correct } \\
\text { - drawn in the right place }\end{array}$ \\
\hline & cytoplasm & $\begin{array}{c}\text { No } \\
\text { drawing }\end{array}$ & $\begin{array}{l}\text { - the shape is incorrect } \\
\text { - drawn in the wrong place }\end{array}$ & $\begin{array}{c}\text { - the shape is correct } \\
\text { - drawn in the wrong place }\end{array}$ & $\begin{array}{l}\text { - the shape is incorrect } \\
\text { - drawn in the right place }\end{array}$ & $\begin{array}{l}\text { - the shape is correct } \\
\text { - drawn in the right place }\end{array}$ \\
\hline \multirow{2}{*}{ Nucleus (8) } & micronucleus & $\begin{array}{c}\text { No } \\
\text { drawing }\end{array}$ & $\begin{array}{l}\text { - the shape is incorrect } \\
\text { - drawn in the wrong place }\end{array}$ & $\begin{array}{c}\text { - the shape is correct } \\
\text { - drawn in the wrong place }\end{array}$ & $\begin{array}{l}\text { - the shape is incorrect } \\
\text { - drawn in the right place }\end{array}$ & $\begin{array}{l}\text { - the shape is correct } \\
\text { - drawn in the right place }\end{array}$ \\
\hline & macronucleus & $\begin{array}{c}\text { No } \\
\text { drawing }\end{array}$ & $\begin{array}{l}\text { - the shape is incorrect } \\
\text { - drawn in the wrong place }\end{array}$ & $\begin{array}{c}\text { - the shape is correct } \\
\text { - drawn in the wrong place }\end{array}$ & $\begin{array}{l}\text { - the shape is incorrect } \\
\text { - drawn in the right place }\end{array}$ & $\begin{array}{l}\text { - the shape is correct } \\
\text { - drawn in the right place }\end{array}$ \\
\hline
\end{tabular}

Table 3. Drawing levels of pre-service science teachers

\begin{tabular}{ll}
\hline Levels & Drawings \\
\hline 1 & No drawing or irrelevant drawing(s) \\
\hline 3 & $\begin{array}{l}\text { Partially correct drawing: } \\
\text { One example (e.g. amoeba, euglena, paramecium, algae etc.) for protists indicating some parts of it in the right places. }\end{array}$ \\
\hline 4 & $\begin{array}{l}\text { Partially correct drawing: } \\
\text { One example for protists indicating all parts of it in the right places. }\end{array}$ \\
\hline 5 & Partially correct drawing: \\
& Two examples for protists indicating some parts of them in the right places. \\
& Partially correct drawing: \\
& Partially correct drawing: \\
& $\begin{array}{l}\text { Three examples for protists indicating some parts of them or all parts of one/ two and some parts of one/ two of them in the right } \\
\text { places. }\end{array}$ \\
\hline 7 & Comprehensive representation: \\
& Three examples for protists indicating all parts of them in the right places.
\end{tabular}

Based on the scoring system, firstly, the pre-service teachers' black-and-white drawings related to the protists concept were grouped under three categories: 1) No/ irrelevant drawing (level 1), 2) partially correct drawing (level 2-6), 3) completely correct drawing (level 7). Then, the participants' conceptual understandings were analyzed and grouped based on their levels. In order to determine these levels, data were grouped from level 1 to level 7. These seven levels of conceptual understanding, which were adapted from the drawing scoring system of Reiss and Tunnicliffe (2001), are given in Table 3.

After grouping the conceptual understandings of the participants based on Tables 1, 2 and 3, reliability and validity analyses were conducted. In qualitative studies, concepts of credibility, transferability, consistency, and confirmability are used instead of validity and reliability (Koch, 2006; Miles \& Huberman, 1994). Therefore, in this study, reliability percentage was calculated based on Miles and Huberman's (1994) formula: "Reliability = [Agreement/ (Agreement + Disagreement)]". In this regard, collected data were analyzed separately by two experts, and the agreement level between the experts was checked for consistency.

\section{Writing}

The pre-service science teachers are expected to indicate the main characteristics of the protists in their writings. The six main characteristics of the protists are (Britannica, 2017):

1. They are eukaryotic (their cells have a nucleus and other membrane-bound organelles),

2. Most of them are unicellular (they have only one cell), but not all.

3. Most of them live in water, damp soil, sand, moist leaf litter, and other damp or wet locations.

4. Most of them reproduce asexually through binary fission (nucleus splits in two), whereas some of them reproduce by multiple fission (many nuclei divide), budding, and fragmentation. Still others reproduce by sexual reproduction.

5. While most of them are capable of motility (using flagella, cilia, pseudopodia etc.), others may be nonmotile for most or part of the life cycle.

6. Some protists engage in photosynthesis, others ingest food they find, and some absorb their food. Some protists exhibit both autotrophic and heterotrophic nutrition.

According to the scoring system, the pre-service science teachers receive 10 points for each completely correct feature of protists. The pre-service teacher who wrote all six features completely correct will receive 60 points. Based on the scoring system, pre-service teachers' writings were grouped under three categories and seven levels: 1) wrong answer (level 1), 2) partially correct answer (level 2-6), 3) clear understanding (level 7). These categories and levels are given in Table 4. 
Table 4. Writing levels of pre-service science teachers

\begin{tabular}{lll}
\hline Levels & Writings & Score interval \\
\hline 1 & No/wrong answer: & 0 \\
& No answer or answer including wrong feature(s) for protists & $1-10$ \\
\hline 3 & Partially correct answer: & $11-20$ \\
& Answer including one feature for protists & $21-30$ \\
\hline 4 & Partially correct answer: & $31-40$ \\
\hline 5 & Answer including two features for protists & $41-50$ \\
\hline 6 & Partially correct answer: & $51-60$ \\
\hline 7 & Answer including three features for protists & \\
& Partially correct answer: & \\
\hline
\end{tabular}

Table 5. Drawing and writing levels of pre-service science teachers regarding protists

\begin{tabular}{|c|c|c|c|c|c|c|c|}
\hline \multicolumn{2}{|c|}{ Drawing levels } & \multirow{2}{*}{$\begin{array}{c}\mathbf{N} \\
7 \\
\end{array}$} & \multirow{2}{*}{$\begin{array}{c}\% \\
11.7 \\
\end{array}$} & \multicolumn{2}{|c|}{ Writing levels } & \multirow{2}{*}{$\begin{array}{c}\mathbf{N} \\
7 \\
\end{array}$} & \multirow{2}{*}{$\begin{array}{c}\% \\
11.7\end{array}$} \\
\hline 1 & low & & & 1 & low & & \\
\hline 2 & low & 19 & 31.7 & 2 & low & 9 & 15.0 \\
\hline 3 & moderate & 11 & 18.3 & 3 & moderate & 20 & 33.3 \\
\hline 4 & moderate & 10 & 16.7 & 4 & moderate & 18 & 30.0 \\
\hline 5 & moderate & 6 & 10.0 & 5 & moderate & 3 & 5.0 \\
\hline 6 & high & 4 & 6.7 & 6 & high & 2 & 3.3 \\
\hline 7 & high & 3 & 5.0 & 7 & high & 1 & 1.7 \\
\hline
\end{tabular}

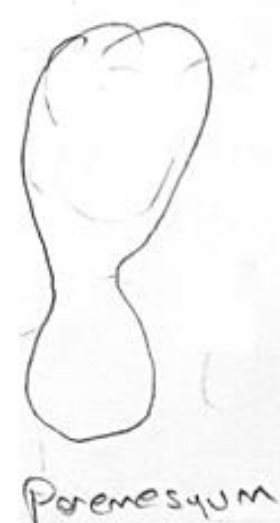

(Paramecium)

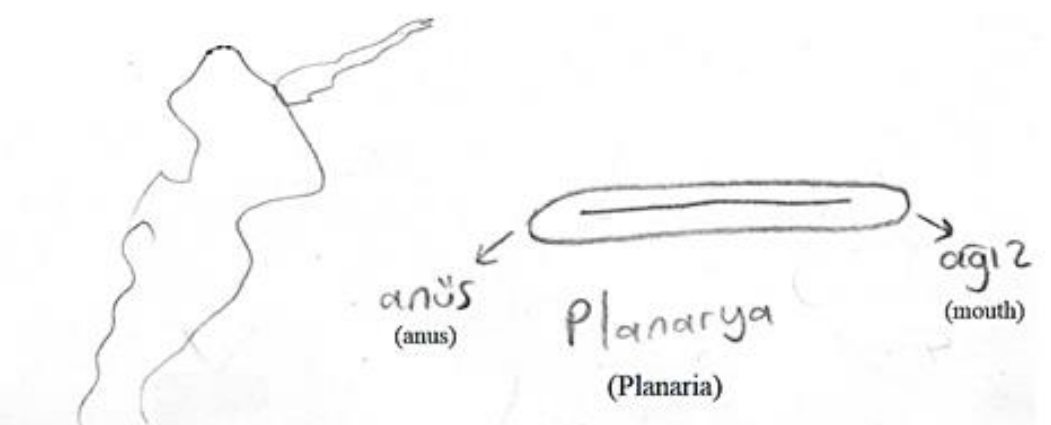

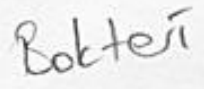

(Bacteria)

Figure 1. Drawing examples of Level 1 (P26)

After grouping the writings of the pre-service science teachers based on Table 4, reliability and validity analyses were conducted. In this regard, collected data were analyzed separately by two experts, and the agreement level between the experts was checked for consistency.

\section{Reliability}

In the study, reliability percentages were calculated based on Miles and Huberman's (1994) formula. As a result of the analyses, the percentages of the agreement between experts regarding the assessment of drawings and writings were measured as 0.92 and 0.90 , respectively. Since the percentage values above $70 \%$ considered reliable (Miles \& Huberman, 1994), these percentages indicate a high reliability.

\section{FINDINGS}

Findings revealed that the pre-service science teachers' knowledge about the protists were identified as moderate. According to Table $5,11.7 \%$ of pre-service science teachers had no or irrelevant drawings (see Figure 1) and writings regarding protists. 


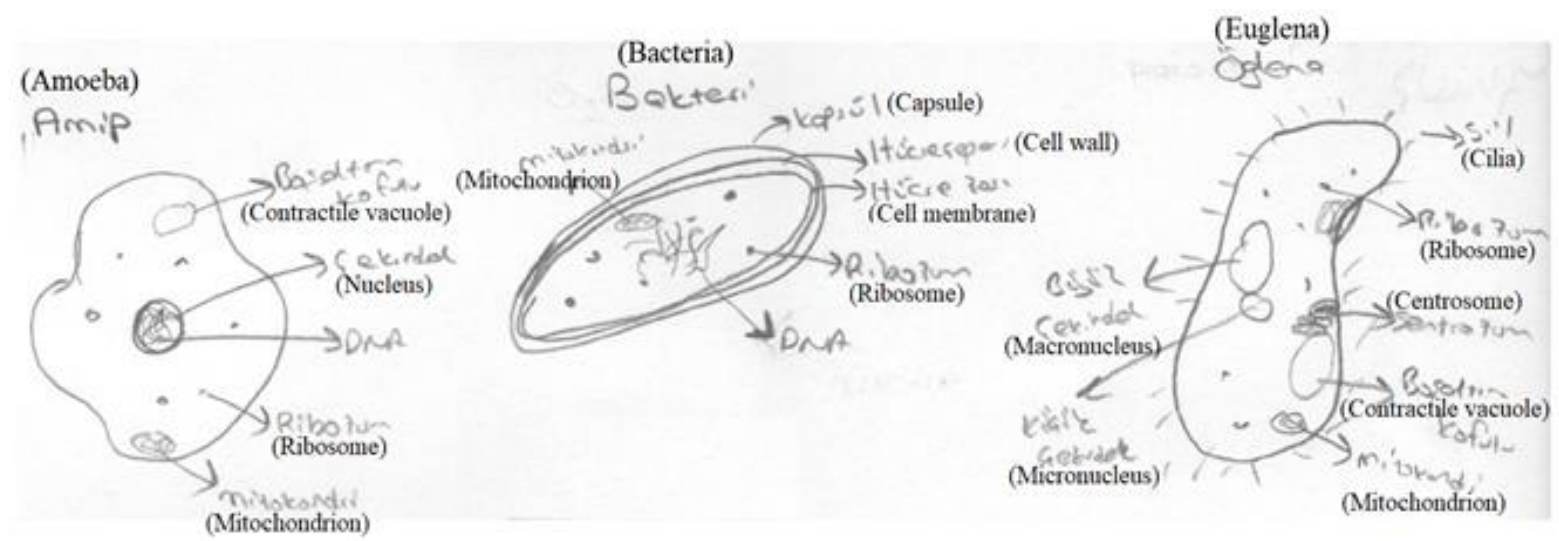

Figure 2. Drawing examples of Level 4 (P24)

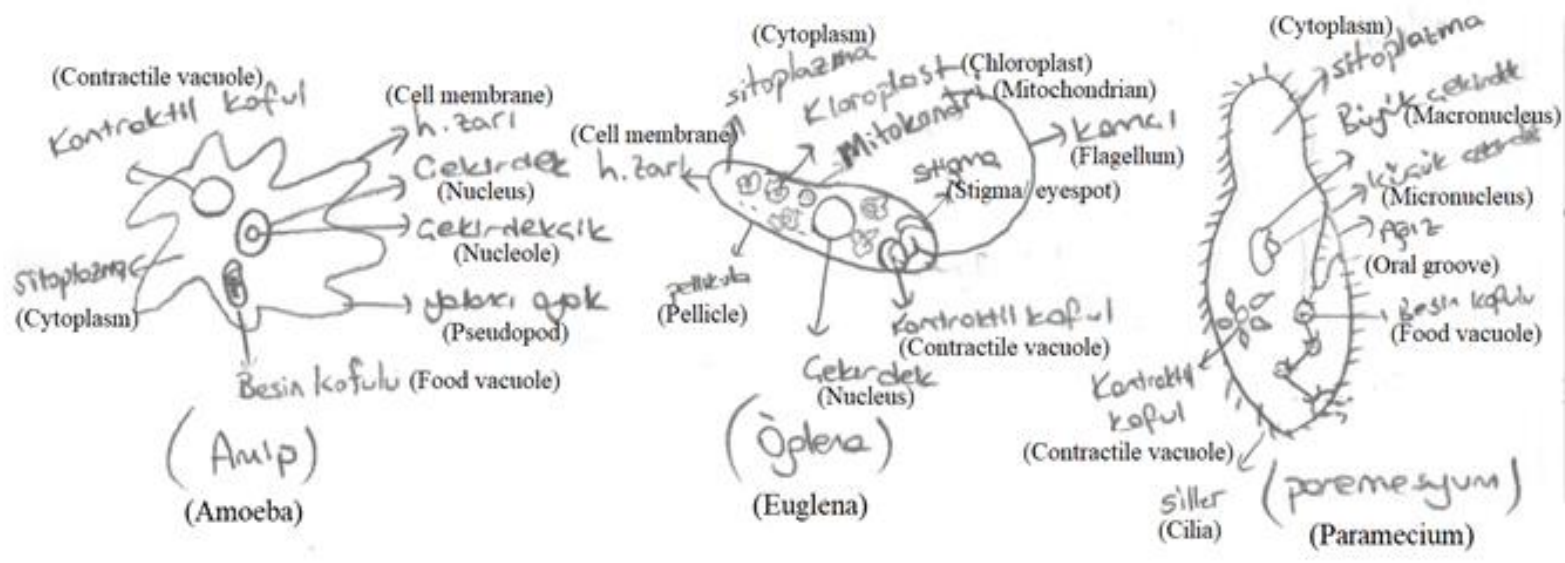

Figure 3. Drawing examples of Level 7 (P9)

Table 6. Some examples from the writing part

\begin{tabular}{ll}
\hline Writing levels & Example \\
\hline 1 & "Protists are prokaryotic organisms. All of them are unicellular." (P38) \\
\hline 5 & $\begin{array}{l}\text { "All of the protists are eukaryotes. Most of them live in water, damp soil, sand or wet locations. While they mostly reproduce } \\
\text { asexually, some of them reproduce by sexual reproduction. They generally move with the help of cilia, flagellum or }\end{array}$ \\
& $\begin{array}{l}\text { "Protists are eukaryotic organisms. The most of them are unicellular and live in damp and wet places like water, damp soil, and } \\
\text { damp moss etc. While most of them reproduce asexually through binary or multiple fission, some protists reproduce through } \\
\text { fragmentation or budding. Still some others reproduce by sexual reproduction. Protists usually move using flagella, pseudopod } \\
\text { or cilia like amoeba, euglena or paramecium. However, some of them are not motile for most or part of their lives. The plant- } \\
\text { like protists (such as algae), are all photosynthetic autotrophs. However, some protists ingest or absorb their food. Also, some } \\
\text { of them are both autotrophic and heterotrophic." (P46) }\end{array}$ \\
&
\end{tabular}

As it is seen in Figure 1, some of the participants drew irrelevant living beings such as bacteria, virus and planaria. While only one of the participants wrote the six features for protists, three participants drew three examples for protists indicating all parts of them (see Figure 3). All three of these pre-service teachers drew the same three protist species namely amoeba, euglena and paramecium.

When Table 5 is examined, it is seen that $83.4 \%$ of the pre-service science teachers had partially correct drawings (see Figure 2), whereas $86.6 \%$ of them had partially correct writings including one to five features for protists. According to Table 5 , the mean level for drawings was calculated as $3.22(S D=.76)$ whereas the mean level for writings was calculated as $3.18(S D=.53)$. As the seven levels given in Table 4 are scaled into low (1-2), moderate (3-5) and high level (6-7), the preservice teachers' knowledge level of protists is accepted as moderate. The drawing examples of Level 1, 4 and 7 are given in Figures 1-3.

Some examples from the writing part are given in Table 6.

Chi-square test was applied to the data in order to see whether there is a significant relationship between drawing and writing levels of the pre-service science teachers. According to Chi-square test results, there is a significant relationship between the preservice teachers' drawing levels and writing levels of protists $\left(\chi^{2}=162.584, d f=36, p<0.05\right)$. According to the $(7 \times 7)$ crosstabulation table (Table 7), students with a high level of writing also have a high level of drawing and vice versa. 
Table 7. Crosstabulation table for drawing and writing levels of the pre-service teachers

\begin{tabular}{|c|c|c|c|c|c|c|c|c|c|c|}
\hline & & & \multicolumn{7}{|c|}{ Writing Level } & \multirow{2}{*}{ Total } \\
\hline & & & 1 & 2 & 3 & 4 & 5 & 6 & 7 & \\
\hline \multirow{14}{*}{ Drawing Level (DL) } & \multirow{2}{*}{1} & Count & 1 & 6 & 0 & 0 & 0 & 0 & 0 & 7 \\
\hline & & $\%$ within DL & $14.3 \%$ & $85.7 \%$ & $0.0 \%$ & $0.0 \%$ & $0.0 \%$ & $0.0 \%$ & $0.0 \%$ & $100.0 \%$ \\
\hline & \multirow{2}{*}{2} & Count & 4 & 3 & 11 & 1 & 0 & 0 & 0 & 19 \\
\hline & & \% within DL & $21.1 \%$ & $15.8 \%$ & $57.9 \%$ & $5.3 \%$ & $0.0 \%$ & $0.0 \%$ & $0.0 \%$ & $100.0 \%$ \\
\hline & \multirow{2}{*}{3} & Count & 2 & 0 & 5 & 4 & 0 & 0 & 0 & 11 \\
\hline & & \% within DL & $18.2 \%$ & $0.0 \%$ & $45.5 \%$ & $36.4 \%$ & $0.0 \%$ & $0.0 \%$ & $0.0 \%$ & $100.0 \%$ \\
\hline & \multirow{2}{*}{4} & Count & 0 & 0 & 4 & 6 & 0 & 0 & 0 & 10 \\
\hline & & \% within DL & $0.0 \%$ & $0.0 \%$ & $40.0 \%$ & $60.0 \%$ & $0.0 \%$ & $0.0 \%$ & $0.0 \%$ & $100.0 \%$ \\
\hline & \multirow{2}{*}{5} & Count & 0 & 0 & 0 & 6 & 0 & 0 & 0 & 6 \\
\hline & & \% within DL & $0.0 \%$ & $0.0 \%$ & $0.0 \%$ & $100.0 \%$ & $0.0 \%$ & $0.0 \%$ & $0.0 \%$ & $100.0 \%$ \\
\hline & \multirow{2}{*}{6} & Count & 0 & 0 & 0 & 1 & 3 & 0 & 0 & 4 \\
\hline & & \% within DL & $0.0 \%$ & $0.0 \%$ & $0.0 \%$ & $25.0 \%$ & $75.0 \%$ & $0.0 \%$ & $0.0 \%$ & $100.0 \%$ \\
\hline & \multirow{2}{*}{7} & Count & 0 & 0 & 0 & 0 & 0 & 2 & 1 & 3 \\
\hline & & \% within DL & $0.0 \%$ & $0.0 \%$ & $0.0 \%$ & $0.0 \%$ & $0.0 \%$ & $66.7 \%$ & $33.3 \%$ & $100.0 \%$ \\
\hline \multirow{2}{*}{\multicolumn{2}{|c|}{ Total }} & Count & 7 & 9 & 20 & 18 & 3 & 2 & 1 & 60 \\
\hline & & \% within DL & $11.7 \%$ & $15.0 \%$ & $33.3 \%$ & $30.0 \%$ & $5.0 \%$ & $3.3 \%$ & $1.7 \%$ & $100.0 \%$ \\
\hline
\end{tabular}

\section{DISCUSSION}

Results of the study indicated that approximately $12 \%$ of the pre-service teachers did not make any drawings and did not write or draw irrelevant drawings and wrote irrelevant writings. For example, some pre-service teachers included irrelevant creatures such as planaria, flatworms, virus and bacteria in their drawings. In parallel with this finding, some other studies revealed that preservice biology and science teachers confused protists with the viruses and bacteria mostly (Kalayci, 2017; Kurt \& Ekici, 2013). Similarly, in a study conducted with high school students, it was revealed that the students had the wrong information about the definition of protists and their characteristics (Yunanda, Susilo \& Ghofur, 2019).

According to the findings obtained from the writings and drawings in the present study, the pre-service science teachers' knowledge about the protists were identified as moderate. Ustun (2011) examined some biology textbooks used between 1937 to 2008 years in Turkey for his research. It was found that flagellates were stated to be partly plants and partly animals, and amoeba and paramecium are given as examples to single celled animals in these books, whereas both creatures are classified as protists today. This may be considered as one of the reasons that affected the pre-service teachers' knowledge level negatively. In other words, the pre-service science teachers may have obtained incomplete or incorrect information about protists from their science and biology teachers, who did not update their content knowledge. Another reason may be that, even though pre-service science teachers observe some of the protists under a light microscope in the Laboratory Applications in Science Teaching course, it is impossible to see every part of each protist through the microscope. Therefore, considering that Dale (1969) theorized that the students gain more information by what they do as opposed to what is heard or read, the pre-service science teachers' observations may be inadequate.

The findings showed that only three of the pre-service teachers drew three protists including all parts. It is noteworthy that all three of these pre-service teachers drew the same three protists -amoeba, euglena and paramecium. Similarly, most of the preservice teachers drew examples of amoeba, euglena and paramecium. In parallel with this finding, in the study conducted by Bektasli (2018), pre-service teachers also made drawings containing these three creatures as examples for protists. The main reason for this situation may be that these three protists are the most frequent examples to protists at different textbooks of all educational levels for years (e.g. MoNE, 2018; NCSU, 2004; Ustun, 2011).

\section{SUGGESTIONS}

According to the findings obtained from the research, it is stated that the pre-service science teachers had a moderate knowledge level of protists. In other words, protists is difficultly understood by the pre-service science teachers. The pre-service teachers who have a moderate level of knowledge on this subject may cause some misconceptions in their students as they cannot transfer sufficient information to their students in the future. For this reason, it is very important to prepare the university textbooks to prevent the misconceptions of pre-service teachers and to cleanse these books from the factors that make learning difficult (Yagbasan \& Gulcicek, 2003). In addition to this, in order to increase the knowledge level of pre-service science teachers it is thought that it may be appropriate to use instructional approaches and methods that appeal to visual based constructivist approach. From this point of view, the courses such as General Biology-I and II, and Laboratory Applications in Science Teaching which include protists concept should be revised. The pre-service science teachers should have the opportunity to observe more protist species under the microscope in Laboratory Applications in Science Teaching course.

The pre-service science teachers may partly find the microscopic creatures to be abstract and have difficulty in understanding because not all parts of them can be observed using a light microscope. By using the tools such as tablets, smartboard etc., they would be able to understand the structure of protist species and their parts which are not discernible through microscope 
(Domjanić Drozdek, Feher Turković, Mojsović Ćuić, \& Digula, 2020). Visual material should be used especially in the education of microbiological concepts that are not visible. Similarly, in their study Demirkus, Ertas and Gulen (2018) suggested to use visual materials especially in teaching of microbiological concepts that are not visible.

This study is limited with the protists subject. Further studies can be done for different biology subjects using drawing-writing technique. Also this study focused on the knowledge level of pre-service science teachers. It is recommended to investigate the pre-service science teachers' misconceptions on protists.

\section{REFERENCES}

Bektasli, F. (2018). Preservice science and biology teachers' knowledge level and misconceptions about archaebacteria, bacteria and protista kingdoms (Master's thesis), Hacettepe University, Turkey.

Cain, A. J. (2020). Division of organisms into kingdoms in Taxonomy. Encyclopedia Britannica. Retrieved on 20 July 2020 from https://www.britannica.com/science/taxonomy/Making-a-classification

Chang, N. (2017). Appropriate integration of children's drawings in the acquisition of science concepts. In P. Katz (Ed.), Drawing for science education: An international perspective. https://doi.org/10.1007/978-94-6300-875-4_12

Chen, Y. C., Hand, B., \& McDowell, L. (2013). The effects of writing-to-learn activities on elementary students' conceptual understanding: Learning about force and motion through writing to older peers. Science Education, 97(5), 745-771. https://doi.org/10.1002/sce.21067

Creswell, J. W. (2013). Research design: Qualitative, quantitative, and mixed methods approaches. Sage publications.

Dale, E. (1969). Audio-visual methods in teaching (3rd ed.). New York: Holt, Rinehart \& Winston. https://doi.org/10.1080/09523986908547873

Demirkus, N., Ertas, A., \& Gulen, S. (2018), Mikrobiyolojik kavramların öğretilmesine ilişkin ders materyali geliştirme çalışması. Kırşehir Eğitim Fakültesi Dergisi, 19(3), 2561-2572. https://doi.org/10.29299/kefad.2018.19.03.021

Denis Celiker, H. (2015). Prospective science teachers' levels of understanding and explanation of animal and plant cells: Drawwrite. Journal of Baltic Science Education, 14(4), 501-512.

Domjanić Drozdek, S., Feher Turković, L., Mojsović Ćuić, A., \& Digula, O. (2020). The role of the iPad tablet in higher education science teaching. Pedagogical Research, 5(1), 1-7. https://doi.org/10.29333/pr/6339

Educational Technology Clearinghouse (ETC), University of South Florida (USF). (2011). Volvox. Retrieved on 5 April 2019 from https://etc.usf.edu/

Eser, H., Cetin, G., Ozarslan, M., \& Isik, E. (2015). Investigation of the prospective biology teachers' views about microbes through the draw and write technique. International Journal of Education, Science and Technology, 1(1), 17-25.

Fraenkel, J. R., Wallen, N. E., \& Hyun, H. H. (2012). How to design and evaluate research in education. New York: McGraw-Hill.

Gagné, R. (1985). The conditions of learning (4th ed.). New York: Holt, Rinehart \& Winston.

Gagné, R. M., Briggs, L. J., \& Wager, W. W. (1992). Principles of instructional design. America: Holt, Rinehart \& Winston.

Huebner, T. (2008). Balancing the concrete and the abstract. Educational Leardership, 66(3), 86-87.

Jalmo, T., \& Suwandi, T. (2018). Biology educaiıon students' mental models on genetic concepts. Journal of Baltic Science Education, 17(3), 474-485.

Joung, Y. J., \& Gunstone, R. (2010). Children's typically-perceived-situations of force and no force in the context of Australia and Korea. International Journal of Science Education, 32(12), 1595-1615. https://doi.org/10.1080/09500690903159352

Kalayci, S. (2017). Determining pre-service science teachers' cognitive structure on the concepts of "prokaryote" and "eukaryote". E-International Journal of Educational Research, 8(3), 46-64. https://doi.org/10.19160/ijer.337877

King, B. M., Rosopa, P. J., \& Minium, E. W. (2011). Statistical Reasoning in the Behavioral Sciences (6th ed.). Hoboken, NJ: John Wiley \& Sons.

Koch, T. (2006). Establishing rigour in qualitative research: The decision trail. Journal of advanced nursing, 53(1), 91-100. https://doi.org/10.1111/j.1365-2648.2006.03681.x

Kurt, H., \& Ekici, G. (2013). Determining biology student teachers' cognitive structure and alternative concepts on the concept of "bacteria". Electronic Turkish Studies, 8(8), 885-910. https://doi.org/10.7827/TurkishStudies.4964

Miles, M. B., \& Huberman, A. M. (1994). Qualitative data analysis. Thousand Oaks, CA: Sage.

Ministry of National Education [MoNE]. (2018). Primary and secondary schools science curriculum (Grades 3, 4, 5, 6, 7 and 8). Ankara.

North Carolina State University (NCSU). (2004). Sample descriptive lab report: Examination of protozoan cultures to determine cellular structure and motion pattern. Retrieved on 4 April 2019 from https://labwrite.ncsu.edu/

Nugraha, I. (2018, May). The use of drawing as an alternative assessment tool in biology teaching. In Journal of Physics: Conference Series (Vol. 1013, No. 1, p. 012016). IOP Publishing. https://doi.org/10.1088/1742-6596/1013/1/012016

Ormanci, U., \& Balim, A. G. (2016). The determination of science teacher candidates' ideas on cell subject through drawing method. The Online Journal of New Horizons in Education, 6(2), 112-123. 
Patrick, P. G., \& Tunnicliffe, S. D. (2010). Science teachers' drawings of what is inside the human body, Journal of Biological Education, 44(2), 81-87. https://doi.org/10.1080/00219266.2010.9656198

Pope, D. (2019). Understanding subject knowledge for primary teaching. Learning Matters, SAGE.

Quillin, K., \& Thomas, S. (2015). Drawing-to-learn: a framework for using drawings to promote model-based reasoning in biology. CBE-Life Sciences Education, 14(1), 1-16. https://doi.org/10.1187/cbe.14-08-0128

Raharjo, D., Ramli, M., \& Rinanto, Y. (2018). Misconception protist in high school biology textbooks. In International Conference on Mathematics and Science Education of Universitas Pendidikan Indonesia, 3, 85-90.

Reiss, M. J., \& Tunnicliffe, S. D. (2001). Students' understandings of human organs and organ systems. Research in Science Education, 31(3), 383-399. https://doi.org/10.1023/A:1013116228261

Senemoglu, N. (2009). Öğrenme ürünleri ve öğretimi [Learning products and teaching]. Gelişim, Öğrenme ve Öğretim içinde [In Development, Learning and Teaching]. Ankara: Pegem Akademi.

Skamp, K. (Ed.) (2012). Teaching primary science constructively. Retrieved on 9 September 2019 from https://books.google.com.tr

Slominski, T. N., Momsen, J. L., \& Montplaisir, L. M. (2017). Drawing on student knowledge of neuroanatomy and neurophysiology. Advances in Physiology Education, 41(2), 212-221. https://doi.org/10.1152/advan.00129.2016

Tekkaya, C., Capa, Y., \& Yilmaz, O. (2000). Biyoloji öğretmen adaylarının genel biyoloji konularındaki kavram yanılgıları. Hacettepe Üniversitesi Ĕgitim Fakültesi Dergisi, 18(18), 140-147.

The Editors of Encyclopaedia Britannica. (2017). Protist. Encyclopædia Britannica, Inc. Retrieved on 12 October 2019 from https://www.britannica.com/science/protist/Features-unique-to-protists

Tunnicliffe, S. D. (2011). Visualisation of animals by children: How do they see birds?. CEPS Journal, 1(4), 63-80.

Ustun, H. (2011). Lise biyoloji ders kitaplarında (1937-2008) hücre konusu ile ilgili olarak bilimsel bilginin değişebilir doğası üzerine bir araştırma [A research on the changeable nature of scientific knowledge in relation to the cell subject in high school biology textbooks (1937-2008)] (Unpublished Masters Thesis), Selcuk University, Institute of Education Sciences, Konya, Turkey.

Vance, K., Miller, K., \& Hand, B. (1995). Two examples of using constructivist approaches to teach ecology at the middle school level. The American Biology Teacher, 37(4), 244-249. https://doi.org/10.2307/4449978

Yagbasan, R., \& Gulcicek, C. (2003). Fen öğretiminde kavram yanılgılarının karakteristiklerinin tanımlanması [Defining the characteristics of misconceptions in science teaching]. Pamukkale Üniversitesi Eğitim Fakültesi Dergisi - Pamukkale University Journal of the Faculty of Education, 13, 102-120.

Yang, D., \& Zhou, M. (2017). Exploring lower-secondary school students' images and opinions of the biologist. Journal of Baltic Science Education, 16(6), 855-872.

Yunanda, I., Susilo, H., \& Ghofur, A. (2019). Misconceptions identification on biodiversity and protist using multiple choice open reason (MCOR). Biosfer: Jurnal Pendidikan Biologi, 12(2), 170-181. https://doi.org/10.21009/biosferjpb.v12n2.170-181 